\title{
Power quality improvement based on hybrid coordinated design of renewable energy sources for DC link channel DSTATCOM
}

\author{
Ali Nasser Hussain ${ }^{1}$, Ahmed Jadaan Ali ${ }^{2}$, Firas Saaduldeen Ahmed ${ }^{3}$ \\ ${ }^{1,3}$ Department of Electrical Power Engineering Techniques, Electrical Engineering Technical College, \\ Middle Technical University, Iraq \\ ${ }^{2}$ Department of Electrical Power Technology Engineering, Technical Engineering College/Mosul, \\ Northern Technical University, Iraq
}

\section{Article Info \\ Article history: \\ Keywords: \\ DSTATCOM \\ MPPT \\ PV \\ SRF \\ VSC}

Received Mar 6, 2020

Revised Apr 19, 2020

Accepted Apr 29, 2020

\begin{abstract}
This paper presents a comprehensive analysis of power quality for static synchronous compensator on the distribution power system (DSTATCOM) when different types of energy sources are used to supply the DC link channel of DSTATCOM. These types of power supplies have a different effect on the compensation of DSTATCOM due to operation nature of these sources. The dynamic response of the DSTATCOM has investigated that produced by individual and hybrid energy sources to evaluate the influence of these sources in terms of time response, compensation process and reduce the harmonics of current source. Three cases have been considered in this study. First the photovoltaic (PV) cells alone, second the battery storage alone, and third a hybrid coordinated design between (PV cells with battery storage) is used. A boost DC-DC circuit has connected to a photovoltaic cell with maximum power point tracking (MPPT) while DC-DC buck-boost circuit is used with a battery. High coordination between PV and battery circuits in the hybrid system is used to improve the performance. A synchronous reference frame (SRF) with a unit vector has used to control the DSTATCOM. The simulation results show that the hybrid design has a superiority response compared to the individual sources.
\end{abstract}

Copyright $\odot 2020$ Institute of Advanced Engineering and Science. All rights reserved.

Corresponding Author:

Ali Nasser Hussain,

Department of Electrical Power Engineering Techniques,

Electrical Engineering Technical College,

Middle Technical University, Baghdad, Iraq.

Email: alinasser1974@yahoo.com

\section{INTRODUCTION}

Renewable energy sources nowadays become the best choice for solving power generation transmission and distribution problems. Therefore, the researchers focus on their works on this type of topic. The process of extracting employing and using this energy correctly and accurately leads to high-quality results. The process of reaching a rapid response to the power compensation from the renewable energy source that represented the important action to reduce the losses [1,2]. The extraction of photovoltaic power obtained from solar cells renewable energy sources is affected by fluctuating weather conditions such as changing solar radiation, and high temperatures, etc [3]. To increase the maximum benefit of solar panels that generated the power, an MPPT algorithm must be used [4-5]. There are different methods to implement the MPPT algorithm like constant voltage method, open-circuit voltage method, perturb and observe method and incremental conductance (INC) method has been include in the current design $[6,7]$. 
The INC method is applied on the DC to DC boost circuit to get the best pulse to operate the switch insulated gate bipolar transistor (IGBT) used in the boost circuit of PV The INC method is applied on the DC to DC boost circuit to get the best pulses in order to operate the switches of isolated gate bipolar transistor (IGBT) that used in the boost circuit of PV [8]. The DC-DC boost circuit also feeds the DC link of VSC. The surplus power generated by solar panels has stored by an energy store (battery) [9]. The variation of generating power from solar panels according to the weather, and where the absence of solar radiation at night requires extraction of this energy stored in the battery, then is used to supply the DC link. in order to obtain a high accuracy of charge and discharge a buck-boost circuit has been introduced to regulate the output voltage of the battery. Also, to maintain high coordination between the PV panel and battery operation, an additional logical circuit is used to get a hybrid system [10-15].

Many types of equipments were used to improve the power quality like Static Var Compensator (SVC), where this type is considered as traditional because of depending on a large capacitor and inductance in the compensation process [16]. The development of power electronic parts led to the emergence of more advanced equipment of SVC in terms of small size, rapid compensation response and controllability, such as static synchronous compensator (STATCOM), Static synchronous series compensator (SSSC). The combination of (SSSC) and (STATCOM) have resulted from it a more developed device called unified power flow controller (UPFC) this device is considered the best among all FACTS, but it has very complex control circuits in addition to the high construction costs [17]. In present work, the STATCOM device has been used in the power quality because of the control circuit of STATCOM not complicated, small size and high compensation performance [18, 19]. The synchronous reference frame with a unit vector technique is suitable for the control circuit of DSTATCOM [20, 21]. Low power quality is considered, the essential drawback of distribution systems three phase three-wires due to nonlinear loads, unbalanced neutral current of load, etc [22]. IGBT switch has been used as a switching transistor in the VSC to provide a fast response time of the out-put voltage of inverter at the DC-link for DSTATCOM, which in turn beget the desired compensation [23-25].

The contribution of the study is PV-battery works together as a hybrid system to supply the DC link voltage of STATCOM, where this design has applied for the first time. Also, comparison and evaluation among the effects of time response for power compensation of DSTATCOM under different supply sources. A comparison among the suggested compensator of power sources depends on which of them reach the steady-state first. Furthermore, a new control circuit called SRF with a unit vector has been used to ignite the DSTATCOM switches [20,21].

\section{RESEARCH METHOD}

A multi-source compensation system (solar cell and battery) is an efficient approach to compensate for the non-linearity of loads and reduce THD. This system requires a high coordination design of the compensation process [26]. Also, it needs a comparison and evaluation of the performance of these sources. The integration of SRF and unit vector technology are used in the current design.

\subsection{Scheme of DSTATCOM fed from (PV and battery)}

The VSC for DSTATCOM is feeding from multi-renewable sources (PV boost converter circuit and battery buck-boost converter) as shown in Figure 1. the DSTATCOM is connected between grid and non-linear load for compensation. Also, the figure shows the ripple filter is used for filtering the output waveform of a three-phase voltage. The value of the DC-link capacitor voltage $\left(V_{d c_{r e f}}\right)$ in the VSC inverter is calculated by instantaneous power that fed to the DSTATCOM and obtained by the equations below [27]:

$$
V_{d c_{\text {actual }}}=\frac{2 \sqrt{2} V_{\text {Line }}}{\sqrt{3} * m}
$$

Also, the value of capacitor is represented by the following equation [28]:

$$
0.5 C_{d c}\left[\left(V_{d c_{r e f}}^{2}\right)-\left(V_{d c_{a c t u a l}}^{2}\right)\right]=3 V_{p h}\left(O L I_{p . h}\right) t
$$

The value of phase voltage is given by the following equation:

$$
V_{p . h}=\frac{V_{\text {line }}}{\sqrt{3}}
$$


where: $(m)$ is the index of modulation taken $1,\left(V_{d c_{r e f}}\right)$ is the DC-voltage connection reference and equal $680 \mathrm{~V},\left(V_{d c_{\text {actual }}}\right)$ is the DC- actual voltage connection for VSC and equal $677.69 \mathrm{~V},\left(V_{\text {Line }}\right)$ is the line to line voltage of source equals $415 \mathrm{~V},\left(C_{d c}\right)$ is DC-capacitor connection channel equal $3000 \mu F,(O L)$ is the factor of over load taken 1.2, $\left(I_{p . h}\right)$ is the 3-phase of source equals 58.14 Ampere, $\left(V_{p . h}\right)$ is the 3-phase voltage of source equals 240 Volt, the DC-recovery time voltage equal $350 \mu \mathrm{s}$.

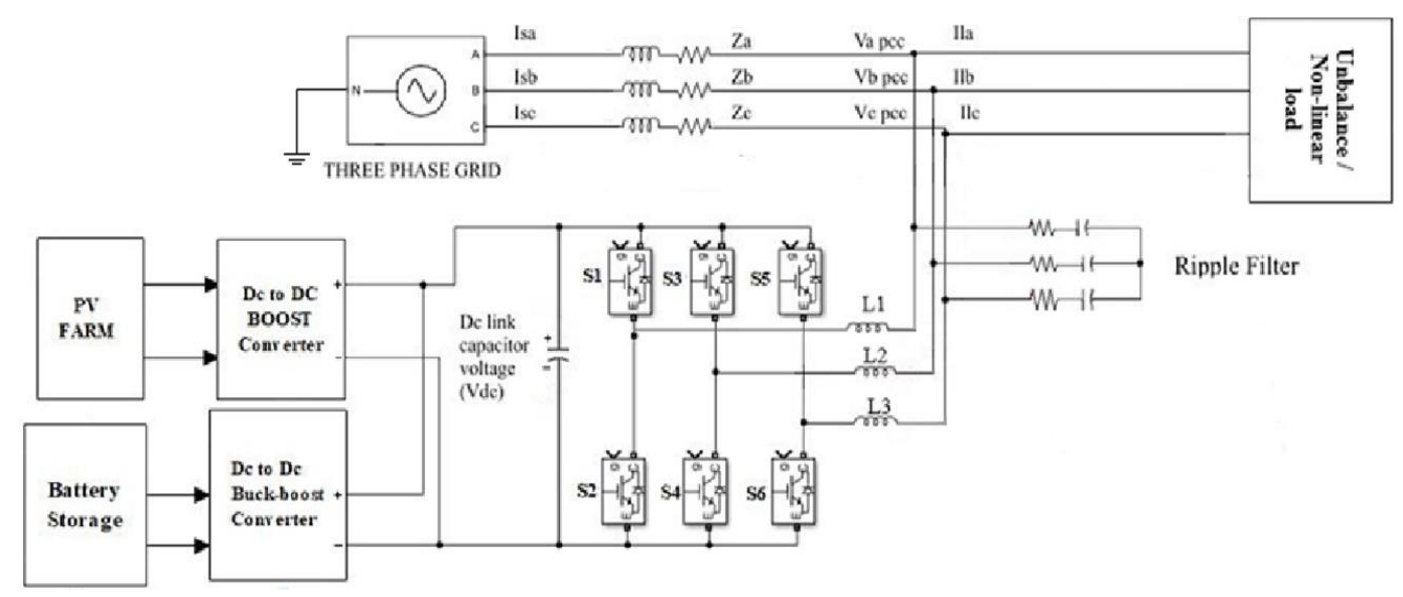

Figure 1. Scheme of the multi-sources (PV cell and store battery) on the DC-link connection for DSTATCOM

\subsection{Modeling of photovoltaic cell (PV)}

PV cells farm includes numerous modules (arrays) that connected in parallel and series methods to obtain the appropriate current and voltage required by a designer. The characteristic of PV panels which have used in the current design (Sanyo-HIT-240HD-E4) kind and the V-I specifications are given in Table 1 [29]. The equivalent circuit of photovoltaic cell has obtained in Figure 2 [27].

Table 1. V-I specifications model datum at $1000 \mathrm{~W} / \mathrm{m}^{2}-25^{\circ} \mathrm{C}$

\begin{tabular}{ll}
\hline Parameters & Sanyo- HIT-240HD-E4 \\
\hline$P_{M P R}$ & $240 \mathrm{~W}$ \\
$V_{o c}$ & $43.5 \mathrm{~V}$ \\
$I_{s h}$ & $7.37 \mathrm{~A}$ \\
Rated of Voltage $(V)$ & $35.5 \mathrm{~V}$ \\
Rated of Current $(I)$ & $6.77 \mathrm{~A}$ \\
Temperature coefficient (T.C) of short circuit current & $2.21 \mathrm{~mA} /{ }^{\circ} \mathrm{C}$ \\
Temperature coefficient (T.C) of open circuit voltage & $-0.109 \mathrm{~V} /{ }^{\circ} \mathrm{C}$ \\
Cell number (Ncell) & 60 \\
\hline
\end{tabular}

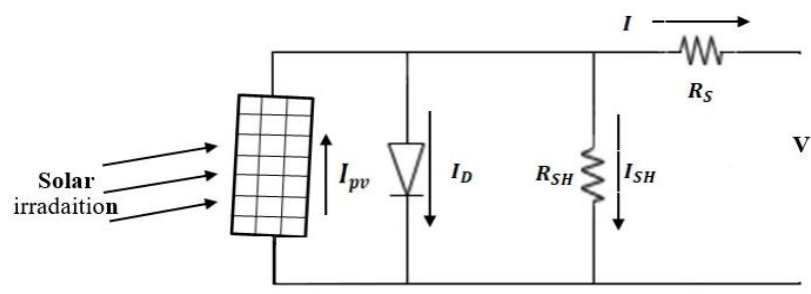

Figure 2. Equivalent circuit of PV cell

The change in the solar irradiation is obtained by equations below [28]:

$$
I=I_{p v}-I_{s a t}\left[\exp \left(\frac{V o c q}{N_{c} K t i}\right)-1\right]-\frac{V o c}{R_{S H}}
$$


$V o c=V+R_{S} I$

Two factor is affects on the current of PV, the first is the irradiation of solar and second is the temperature of solar cell as given in (6).

$$
I_{p v}=\left(I_{p v, s}+K_{t} \Delta_{t}\right) \frac{g}{g_{s}}
$$

The value of $I_{p v, s}$ can be computed using (7)from the equivalent electrical circuit of Figure 2:

$$
I_{p v, S}=\frac{R_{S H}+R_{S}}{R_{S H}} I_{S H}
$$

where: $\left(I_{p v}\right)$ is the photovolotic current diode, $\left(I_{s a t}\right)$ is the saturation current, $\left(N_{c}\right)$ is the seires number of cells, $(K)$ is the constant of boltzmann equals $\left(1.380650 \times 10^{-23} \mathrm{~J} / \mathrm{K}\right),(t)$ is the temperature $\mathrm{p}$-n junction of diode, $(q)$ is charge of elctronic $\left(1.6021764 \times 10^{-19}{ }^{\circ} \mathrm{C}\right),\left(R_{S H}\right)$ is repersented the shunt resistance, the series resistance in equivalent circuit is $\left(R_{S}\right),(i)$ is the ideality factor range between $1 \leq i \leq 1.5$ and taken in this study $1,\left(I_{p v, s}\right)$ is standard of photo-current constant constant $25^{\circ} \mathrm{C}$ of the temperature and $1000 \mathrm{~W} / \mathrm{m}^{2}$ of irradiation, $\left(K_{t}\right)$ is the short circuit of PV-current, $\left(\Delta_{t}\right)$ is the difference between the normal of temperature and actual temperature, $(g$,$) is the irradation of the panel surface and \left(g_{s}\right)$ is the normal irradiation of the panel [27].

\subsection{DC link voltage control strategies}

Two types of control circuits for the voltage of DC link have been considered as follows:

\subsubsection{Photovoltaic boost circuit}

PV cell boost converter has been applied for the suitable supply of DC-link capacitor voltage according to the demand that requirement to be compensated, and as obtained in Figure 1.

a. Maximum power point tracking (MPPT)

In the current work Incremental Conductance (INC) method is considered, which is one of several methods had been used to obtain the maximum power point tracking (MPPT). INC is one of the common methods that used for tracking the power generated by solar panels [30]. INC is used to obtain the suitable duty cycle (D) of IGBT pulse switch [31]. Figure 3 represents the flowchart of the INC algorithm [4].

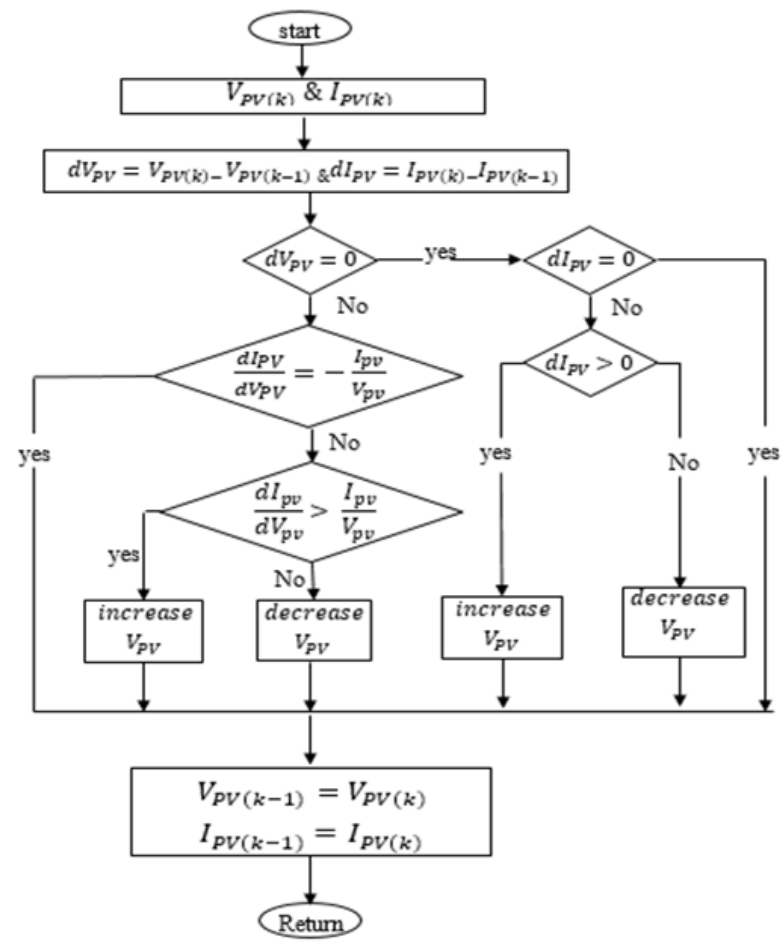

Figure 3. Flowchart of incremental conductance (INC) method 
The MATLAB software environment has been used to simulate the INC method by the following equations [5]:

$$
\begin{aligned}
& \frac{d I_{p v}}{d V_{p v}}=-\frac{I_{p v}}{V_{p v}} \\
& \frac{d I_{p v}}{d V_{p v}}=>\frac{I_{p v}}{V_{p v}} \\
& \frac{d I_{p v}}{d V_{p v}}=<\frac{I_{p v}}{V_{p v}}
\end{aligned}
$$

where: $\left(V_{p v}\right)$ is the voltage of $\mathrm{PV},\left(I_{p v}\right)$ is the current $\mathrm{PV},\left(d V_{p v}\right)$ is the average change values for voltage, $\left(d I_{p v}\right)$ is the average change values for current. The MPP is obtained when the derivative is zero as in the (8). If the power is less than the MPP, the $V_{p v}$ value must be increased to reach MPP according to the (9). If the power is much than the MPP, the $V_{p v}$ value must be decreased to reach MPP according to the (10).

\subsubsection{DC to DC buck-boost converter circuit of battery}

The type of battery used in the present design is a (lead-acid), which is more common in the work with various types of inverters due to the deep cycle of the battery that has a suitable life [32, 33]. As the produced power of the solar panels rises over demand of load, the battery absorbs the excess power via the buck circuit. In absence of PV cell power or low production, the boost circuit operates to compensate for power shortages as shown in Figure 1. The discharge/ charge cycle of a lead acid battery can be obtained by the equations below [12]:

$$
\begin{aligned}
& V_{B_{d i s}}=V-R i_{b}-k \frac{Q}{Q-i(t)}\left(i(t)+t^{f}\right)+\exp (t) \\
& V_{B_{c h}}=V-R i_{b}-\left[k \frac{Q}{i(t)-0.1 Q}\right] i^{f}-\left[k \frac{Q}{Q-i(t)}\right] i(t)+\exp (t) \\
& i(t)=\int i_{b} d(t)
\end{aligned}
$$

where: $\left(V_{B_{-} c h}\right)$ are the battery charge voltage, $\left(V_{B_{-} \text {dis }}\right)$ is the discharge voltage of battery, (Volt) is the fixed voltage or constant voltage of battery $(k)$ is the polarisation of battery (Volt/Ah), $(Q)$ is the the amplitude of battery $(\mathrm{Ah}),(i(t))$ is the actual charge of battery $(\mathrm{A} / \mathrm{h})$, is computed by $(16)$. $\left(i_{b}\right)$ is the actual of battery current (Ampere), $\left(i^{f}\right)$ is the current of filter (Ampere) and $\left(t^{f}\right)$ is the time filter of battery (hour).

\subsubsection{Coordination between PV cell and battery}

High coordination is very important to manage the power generated from different sources. The PV cells power, the power of the battery, the out-put power of inverter, and the percentage or status of charge/discharge (SOC \%) accessible in the battery needs a reliable control device to ensure good efficiency in the supply of DC-link voltage. Figure 4 shows a logical coordination circuit among PV panel, battery, inverter and SOC \% [12].

\subsection{Control circuit of DSTATCOM}

There are many types of control schemes had been applied to simulate the reference currents of source for the DSTATCOM control circuits. Synchronous Reference Frame (SRF) theory, decoupled current control. In the present paper a SRF based unit vector technique has been used instead of Phase Locked Loop (PLL) technique [20, 21, 34, 35]. The drawbacks of PLL technique are the phase jumps caused by undesired frequency swings and startup disturbance [36]. Therefore PLL technique is replaced by the unit vector technique to find the $(\sin \theta, \cos \theta)$ from the voltage of common coupled point $\left(V_{a b c-} P C C\right)$ and given by the following equations [21].

$$
\left[\begin{array}{l}
V_{\alpha} \\
V_{\beta}
\end{array}\right]=\left[\begin{array}{ccc}
1 & -\frac{1}{2} & -\frac{1}{2} \\
0 & \frac{\sqrt{3}}{2} & -\frac{\sqrt{3}}{2}
\end{array}\right]\left[\begin{array}{l}
V_{a} \\
V_{b} \\
V_{c}
\end{array}\right]
$$




$$
\begin{aligned}
& V_{T}=\sqrt{V_{\alpha}^{2}+V_{\beta}^{2}} \\
& \cos \theta=\frac{V_{\alpha}}{V_{T}} \\
& \sin \theta=\frac{V_{\beta}}{V_{T}}
\end{aligned}
$$

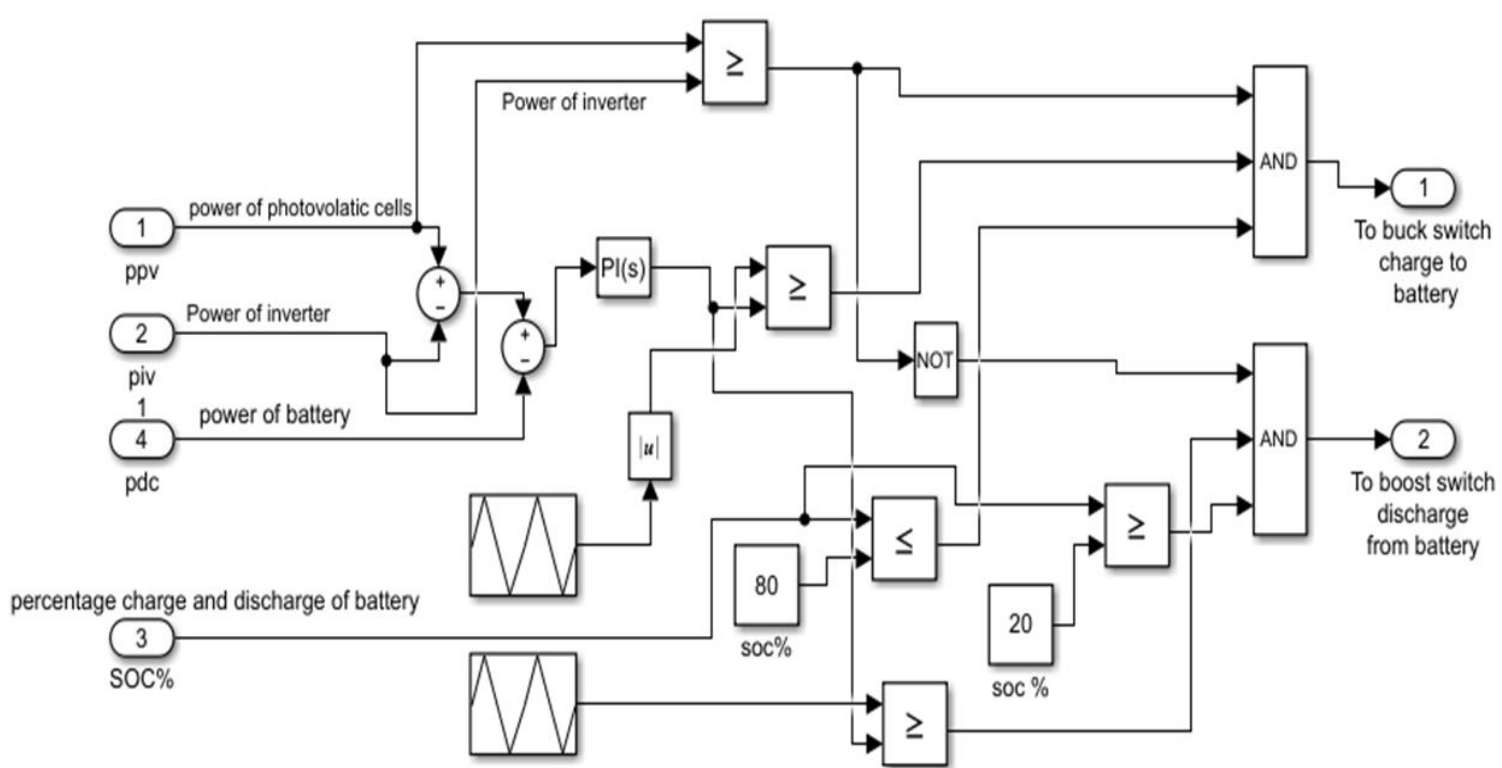

Figure 4. Logical coordination circuit among (PV, battery, and inverter)

The three phases of voltages of DSTATECOM are obtained from the common coupling point $V_{a b c-} P C C$, where it transformed into $(\cos \theta, \sin \theta)$ using a unit vector. In addition, $V_{a b c-} P C C$ is providing to compute the magnitude of these voltages $\left(V_{T}\right)$ after then it is compared with the reference magnitude of voltage $\left(V_{\text {T.ref }}\right)$ to give the error signal as shown in Figures 5 and 6.

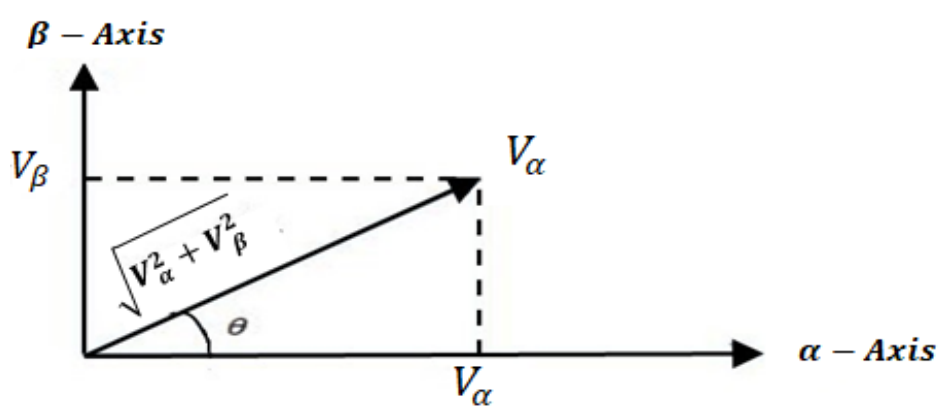

Figure 5. Phasor diagram of voltage magnitude by unit vector technique

The error of $\left(V_{T}\right)$ signal is adjusted by PI.2 and convert to amount a current as known $i_{q t}$ as shown in (18) and (19). The Clark and Park transformation matrices are essential to convert the coordination system into (d-q) system and evaluate the reference current value of control signal. The three phase load currents are taking by a reference signal from senser to find the actual current values in (d-q) axis $\left(i_{d d}, i_{q t}\right)$. The conversion matrix has been described in (20). The DC voltage signal $V_{d c}$ is taken by the DC connection voltage signal meter located on the VSC capacitor connection. The DC reference voltage is 
subtracted $\left(V_{d c_{-} \text {ref } f}\right)$ from the $V_{d c}$ actual to obtain on the difference voltage signal and transformed to current (VSC losses of the switch) using PI.1 as described in (21), (22). So, the current $\left(i_{q t}\right)$ adds with $\left(i_{q q}\right)$ to provide the reference current $\left(i_{q_{-} r e f}\right)$, while the real current $\left(i_{d d}\right)$ adds with current loss of converter switches $\left(i_{d . l o s s}\right)$ to taken the final current or reference current $\left(i_{d \_r e f}\right)$ as illustrated in Figure 6.

The reference currents in $(\mathrm{d}-\mathrm{q})$ reference frame $\left(i_{q_{-} r e f}\right)$ and $\left(i_{d_{-} r e f}\right)$ require an inverse from $(\mathrm{d}-\mathrm{q})$ into $(\mathrm{abc})$ reference frame by inverse Clark transformation to obtain on the reference three-phases current in $\left(I_{\text {abc.ref }}\right)$. Then it compares with the three phases of the current source affected to give suitable compensation.

$$
\begin{aligned}
& i_{q t(n)}=i_{q t(n-1)+K_{p q t}\left(V_{A E(n)}-V_{A e(n-1)}\right)+K_{i q t} v_{A E(n)}} \\
& i_{q r e f}=i_{q t}+i_{q q} \\
& {\left[\begin{array}{c}
i_{d d} \\
i_{q q} \\
i_{o}
\end{array}\right]=\left[\begin{array}{ccc}
\sin \theta & \sin \left(\theta-\frac{2 P i}{3}\right) & \sin \left(\theta+\frac{2 P i}{3}\right) \\
\cos \theta & \cos \left(\theta-\frac{2 P i}{3}\right) & \cos \left(\theta+\frac{2 P i}{3}\right) \\
\frac{1}{6} & \frac{1}{6} & \frac{1}{6}
\end{array}\right]\left[\begin{array}{c}
\frac{2 * i L a}{3} \\
\frac{2 * i L b}{3} \\
\frac{2 * i L c}{3}
\end{array}\right]} \\
& i_{d . l o s s(n)}=i_{d . l o s s}(n-1)+K_{p d d}\left(V_{d c E(n)}-V_{d . c E(n-1)}\right)+K_{i d d} v_{d . c e(n)} \\
& i_{d . r e f=i_{d d}+i_{d . l o s s}}
\end{aligned}
$$

where: $\left(V_{A E(n)}\right)$ is the error of signal between reference $\left(V_{T . r e f}\right)$ and the sensed voltage signal for the source, $\left(V_{d c E(n)}\right)$ is the error of signal between sensed signal of DC channel voltage of nth sample and reference, $\left(K_{i d d}, K_{i q t}\right)$ are the gains of integral of PI.1and PI.2, and $\left(K_{p d d}, K_{p q t}\right)$ are the gains of proportional of PI.1 and PI.2.

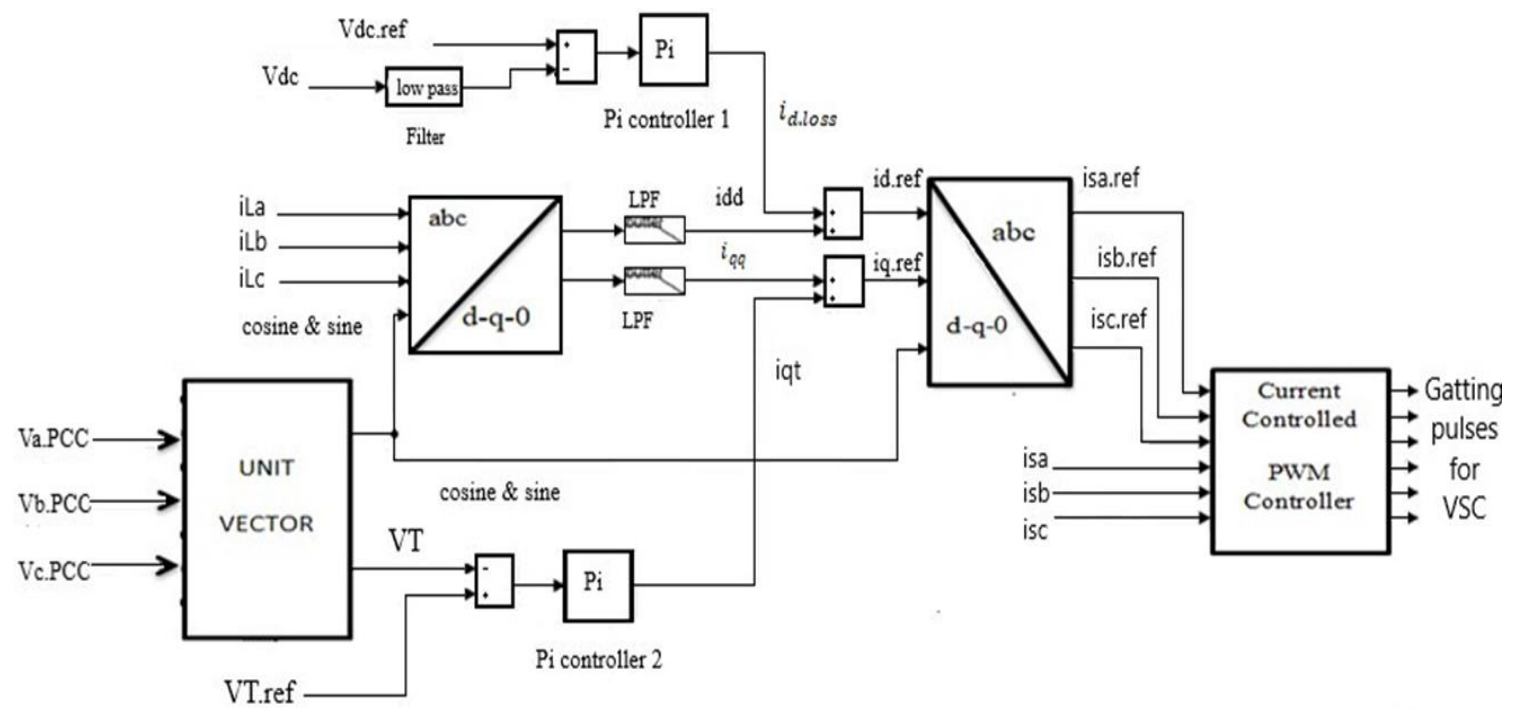

Figure 6. Schematic of control circuit DSTATCOM using SRF with unit vector

\section{RESULTS AND DISCUSSION}

The DSTATCOM with control circuits have been simulated using MATLAB SIMULINK 2018a. The test feeder consists of a three-phase generator and deliveries for the power to a nonlinear load (three-phase rectifier supply R-L load) is used to apply the performance of the suggested hybrid (PV-Battery) configuration. All parameters in the current design are given in Table 2. 
Table 2. Parameters of the system

\begin{tabular}{ll}
\hline Parameters System & Datum \\
\hline Three-phase voltage of Grid and Frequency & $415 \mathrm{~V}, 50 \mathrm{~Hz}$ \\
Line Impedance Per Phase (Rs, Ls) & $0.01 \Omega, 2 \mathrm{mH}$ \\
Non-linear Load & Three phase bridge rectifiers with RL \\
Ripple filter (Rf, Cf). & $5 \Omega, 5 \mu f$ \\
Ac inductor & $3.3 \mathrm{mH}$ \\
DC-link capacitor of DSTATCOM & $3000 \mu f$ \\
DC-link voltage of DSTATCOM & $680 \mathrm{~V}$ \\
DC PI.1 $\left(K_{p d d}, K_{i d d}\right)$ & $0.2,1$ \\
PCC voltage PI.2 $\left(K_{p q t}, K_{i q t}\right)$ & $0.01,2$ \\
PI controller of logical coordination circuit $(\mathrm{KP}, \mathrm{KI})$ & $0.8 * 10^{-9}, 0.8 * 10^{-8}$ \\
The Current and Voltage of Battery $(\mathrm{Vb}, \mathrm{Ib})$ & $550 \mathrm{~V}, 13 \mathrm{Ah}$ \\
\hline
\end{tabular}

Figure 7 shows the waveforms of three phase voltage generator with non-linear load before DSTATCOM compensation. Figure 8 shows the current of phase (A) before the compensation. A feeder line is subjected to interruption between the source and the load during the time of 0.3 to 0.7 second. Figure 9 shows the time response and the effect of cut-off wire (from $0.3 \mathrm{~s}$ to $0.7 \mathrm{~s}$ ) on the DC link of VSC when the DSTATCOM working without support renewable energy sources. From the figure, the time response equals $0.1 \mathrm{~s}$ while the reason $\mathrm{DC}$ voltage rise $710 \mathrm{~V}$, because of decreased the load after cut-off wire (from $0.3 \mathrm{~s}$ to $0.7 \mathrm{~s}$ ) for phase (A).

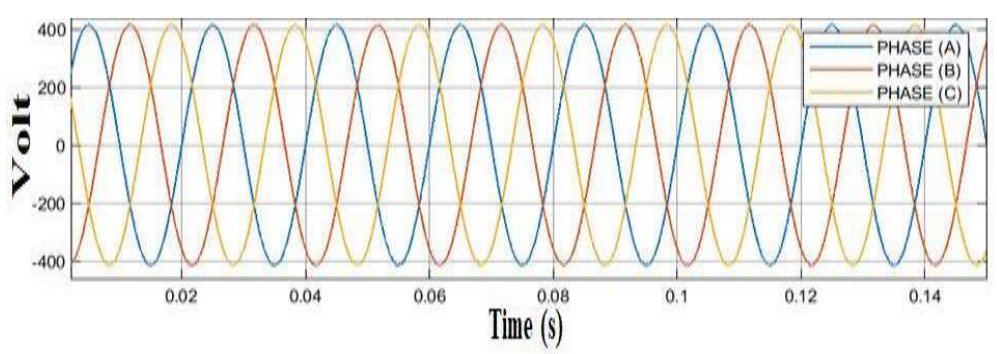

Figure 7. The waveforms of three phase voltage generator

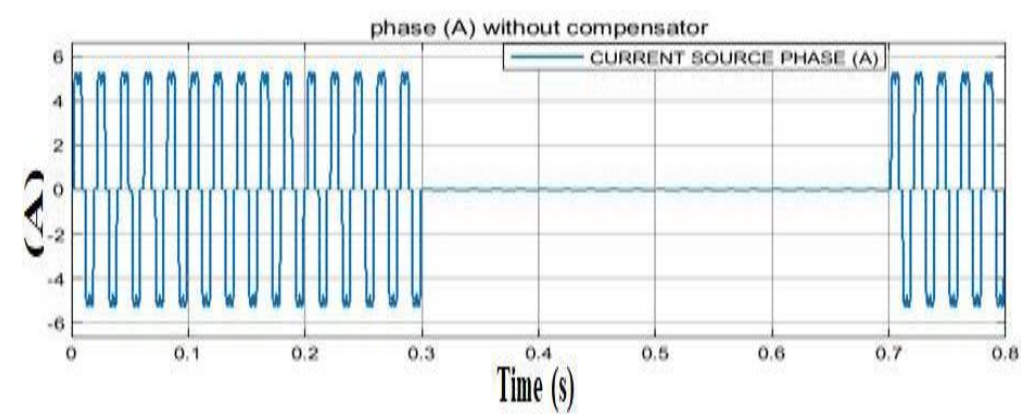

Figure 8. Current source of phase (A) before compansation

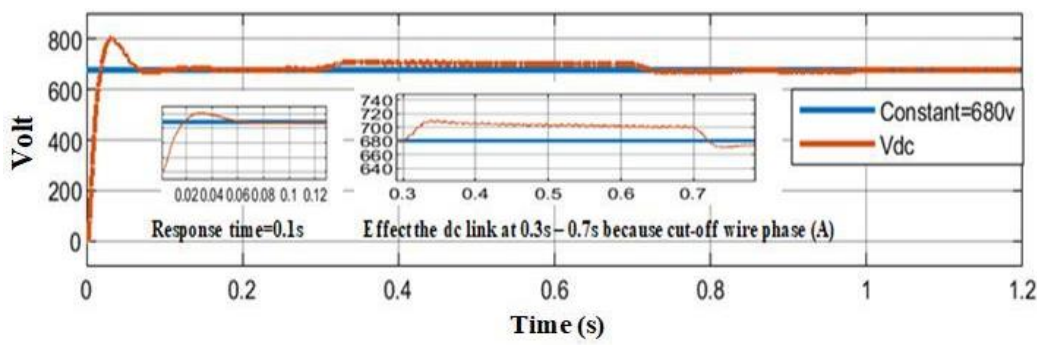

Figure 9. Time response of DC link voltage when DSTATCOM working alone 
Figure 10 shows the time response and the effect of the cut-off wire phase (A) (from $0.3 \mathrm{~s}$ to $0.7 \mathrm{~s}$ ) on the DC link when DSTATCOM provided with battery to supply DC link channel. From Figure 10, it is clear that the time response is less and equal 0.071s while the effect of cut-off wire for phase (A) does not appear in the response time of DC-voltage for DSTATCOM because of rapid compensation of boost converter for the battery.

Figure 11 shows the time response and the effect of cut-off wire for phase (A) on the DC link voltage when the DSTATCOM provided with PV to supply DC link channel. The response time is less than the battery and equal $0.038 \mathrm{~s}$, while the effect of cut-off wire for phase (A) does not appear in the response time of DC-link voltage for DSTATCOM because of rapid compensation of boost converter for PV.

Figure 12 shows the response time on the DC link voltage of VSC when the DSTATCOM provided with multi-renewable energy sources (PV and battery) as a hybrid system to supply the DC link channel. The response time is equal to $0.037 \mathrm{~s}$ while the effect of cut-off wire for phase (A) does not appear in the response time of DC link voltage for DSTATCOM because of rapid compensation of boost converter for the PV cells and buck-boost converter of the battery. And from the $0.2 \mathrm{~s}$ into $1.2 \mathrm{~s}$ appear the effect of the buck-boost circuit for the battery store, and the effect of the boost converter circuit of the PV cells when worked a hybrid system. Figure 13 shows the compensation effect when a constant DC link voltage supplies the DSTATECOM. The performance of a system has been improved related to all previous forms because does not appear any time delay or effects on the DC link voltage.

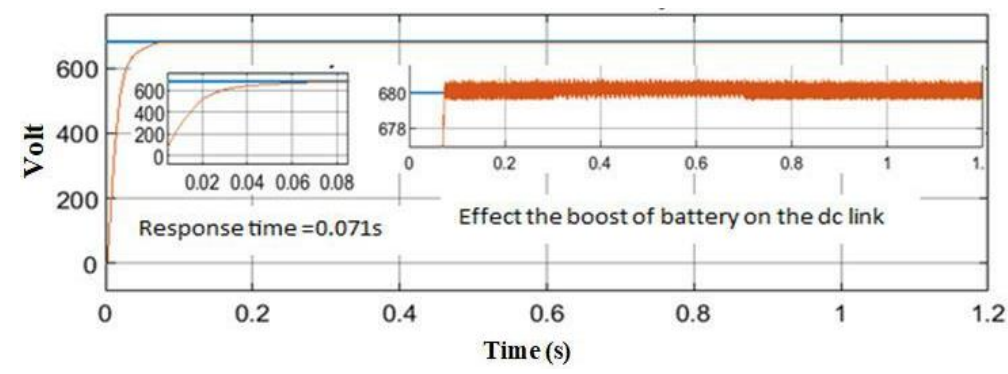

Figure 10. The compensation effect and response time on the of DC link channel voltage when the DSTATCOM is fed from a battery

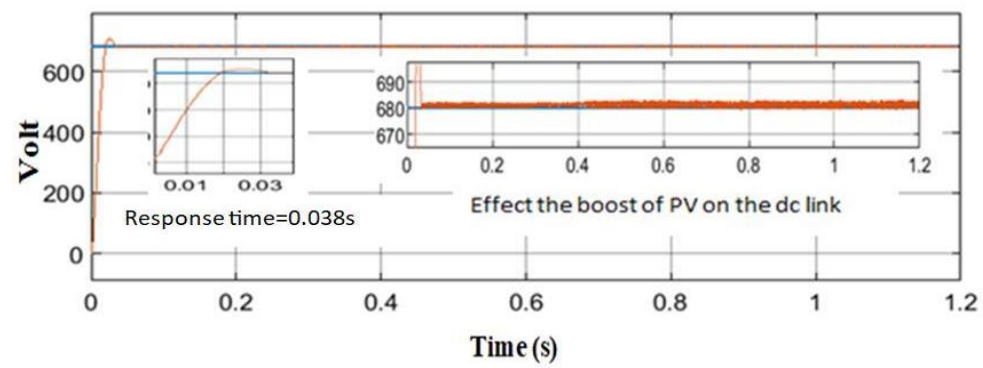

Figure 11. The compensation effect and response time on the DC link channel voltage when the DSTATCOM is fed from PV

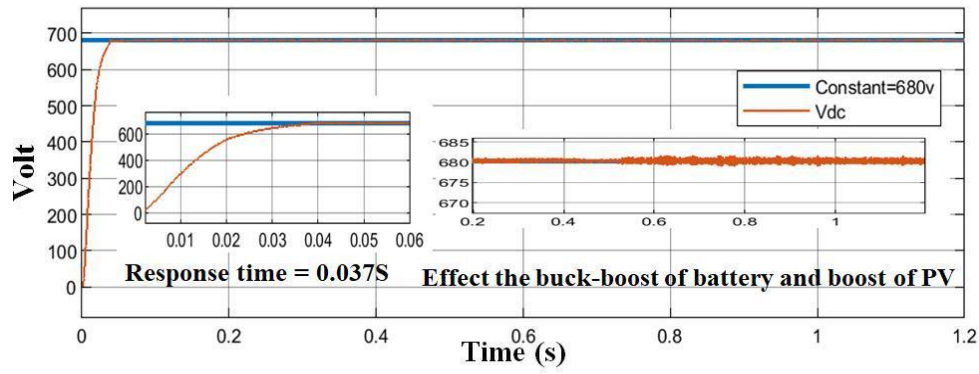

Figure 12. The compensation effect and response time on the DC-link channel connection voltage when the STATCOM is fed from the hybrid system 


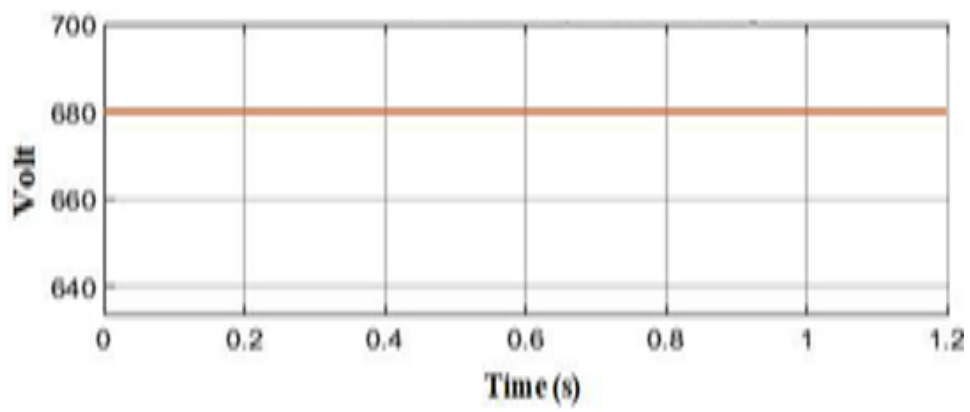

Figure 13. Constant voltage of DC link for the hybrid system

Now, the response times for all the DC-channel cases of DSTATCOM has obtained in Table 3. It is observed the hybrid system given a better response from the other cases. Also, the constant DC-link voltage is an ideal state, it is mentioned for comparison, and it has noted to start with a stable value.

Table 3. Response times for all the DC-channel cases

\begin{tabular}{lllll}
\hline DC-link of VSC for DSTATCOM & Rise Time (s) & Peak Time (s) & $\begin{array}{l}\text { Maximum } \\
\text { overshoot }\end{array}$ & $\begin{array}{l}\text { Settling Time (s) } \\
\text { DC-link without renewable sources }\end{array}$ \\
DC-link with PV cells (alone) & 0.01574 & 0.031 & 123 & 0.108 \\
DC-link with battery (alone) & 0.01465 & 0.02439 & 27 & 0.33 \\
DC-link with PV and battery (hybrid) & 0.0285 & 0 & 0 & 0.07 \\
DC-link with PV and battery (hybrid) at constat DC link & 0.0216 & 0 & 0 & 0.03 \\
\hline
\end{tabular}

Figure 14 shows the Total Harmonic Distortion (THD) of the current source phase (A) before compensation. Figure 15 shows the THD of the current source of the phase (A) after compensation when the DSTATCOM has worked alone without any renewable energy sources. Figure 16 shows the THD of the current source for phase (A) after compensation when the DSTATCOM is connected with battery. Figure 17 shows the THD of the current source for phase (A) when the DSTATCOM is connected with PV at constant irradiation and temperature $\left(1000 \mathrm{~W} / \mathrm{m}^{2}, 25 \mathrm{C}^{\circ}\right)$ respectively to the power system.

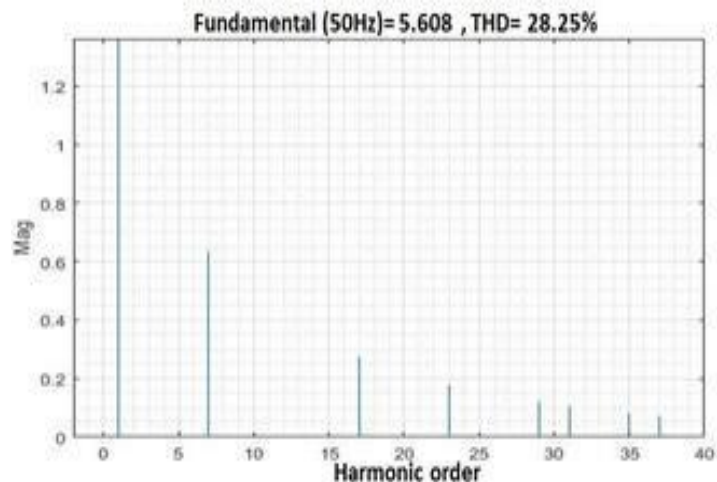

Figure 14. THD for current of phase (A) before DSTATCOM compensation

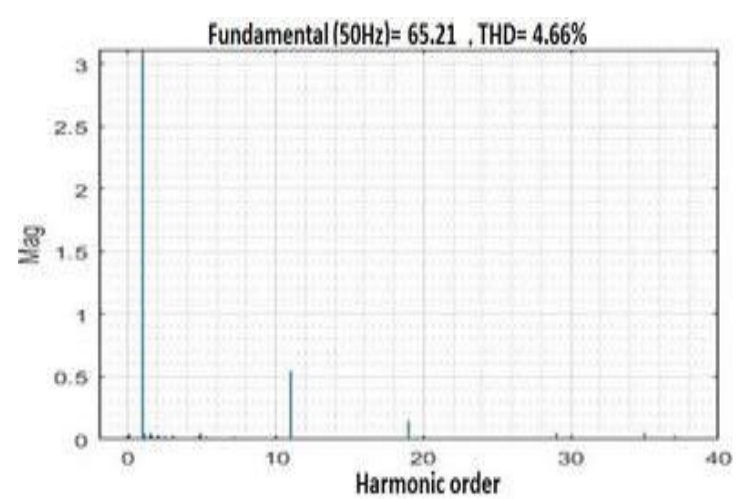

Figure 15. THD for current of phase (A) after the compensation of DSTATCOM alone

Figure 18 shows the THD of the current source for phase (A) after compensation when the DSTATCOM is connected with a hybrid (PV and battery) system at half rated of the PV cells and equal $500 \mathrm{~W} / \mathrm{m}^{2}$ irradiation and constant temperature $25 \mathrm{C}^{\circ}$. Figure 19 shows the THD of the current source phase (A) when the DSTATCOM is connected with hybrid (PV and battery) at a constant voltage of DC link at half rated of the PV cells and equal $500 \mathrm{~W} / \mathrm{m}^{2}$ irradiation and constant temperature $25 \mathrm{C}^{\circ}$. 


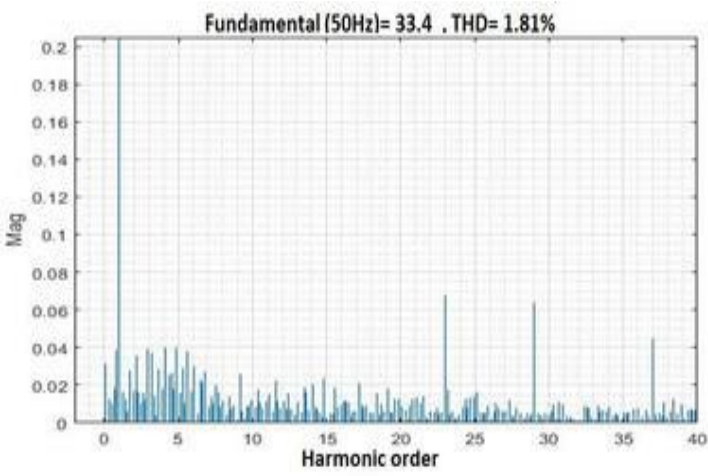

Figure 16. THD for current of phase (A) after the compensation of DSTATCOM with battery

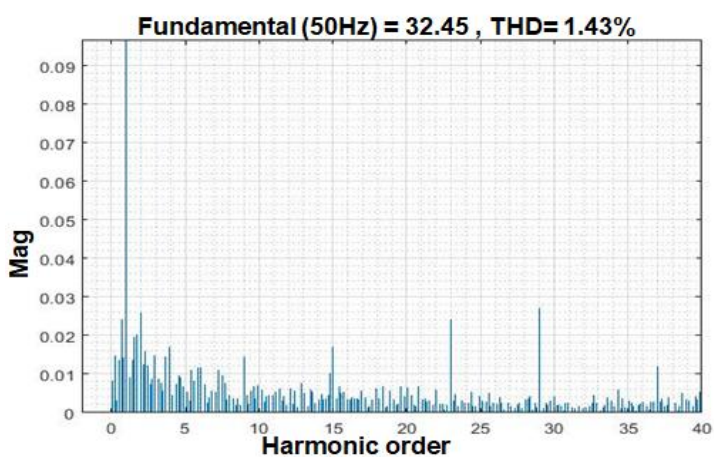

Figure 18. THD for current of phase (A) after the compensation of DSTATCOM with hybrid system

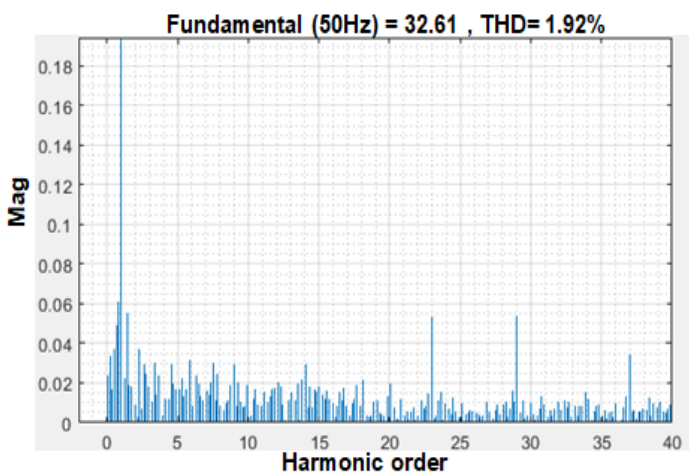

Figure 17. THD for current of phase (A) after the compensation of DSTATCOM with PV

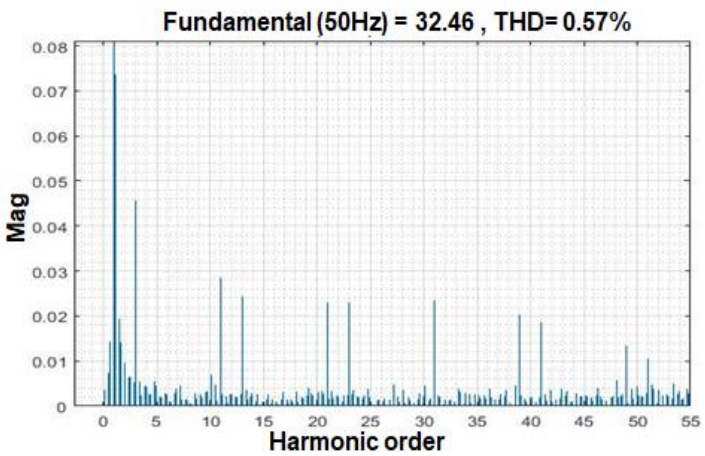

Figure 19. THD for current of phase (A) after the compensation of DSTATCOM with hybrid system at constant voltage of DC link

Figure 20 shows the effects of compensation and response time for DC link voltage on the three phase currents $\left(I s_{a b c}\right)$ source when using the DSTATCOM alone, and in this case the value of $I s_{a b c}$ equal 60A. Figure 21 shows the effects of compensation and response time for DC link voltage on the three phase currents $\left(I s_{a b c}\right)$ source when using the DSTATCOM with battery, and in this case the value of $I s_{a b c}$ equal 32A. Figure 22 shows the effects of compensation and response time for DC link voltage on the three phase currents $\left(I s_{a b c}\right)$ source when using the DSTATCOM with PV, and in this case the value of $I s_{a b c}$ equal 32A.

Figure 23 shows the effects of compensation and response time for DC link voltage on the three phase currents $\left(I s_{a b c}\right)$ source when using the DSTATCOM with hybrid system (battery and PV), and in this case the value of $I s_{a b c}$ equal 32A. Figure 24 shows the effects of compensation and response time for DC link voltage on the three phase currents $\left(I s_{a b c}\right)$ source when using the DSTATCOM with hybrid system (battery and PV) in order to supply constant DC voltage. In this case, the value of (Is $\left.s_{a b c}\right)$ equal $32 \mathrm{~A}$ and the compensation response applied directly without delay time.

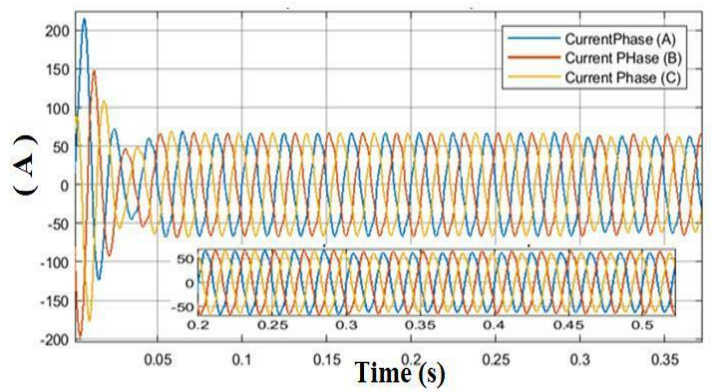

Figure 20. Three-phase currents of source after compensation for DSTATCOM alone 


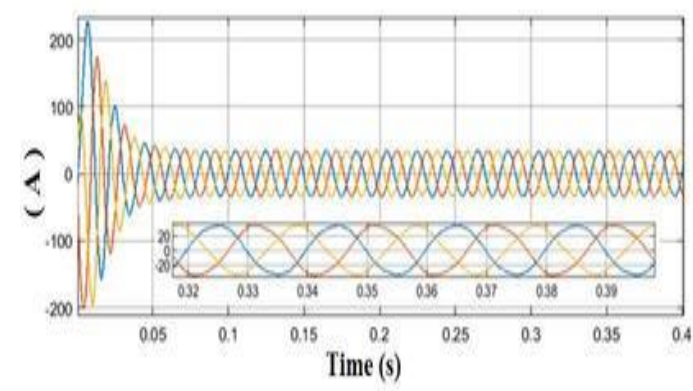

Figure 21. Three-phases current of source after compensation of DSTATCOM with battery

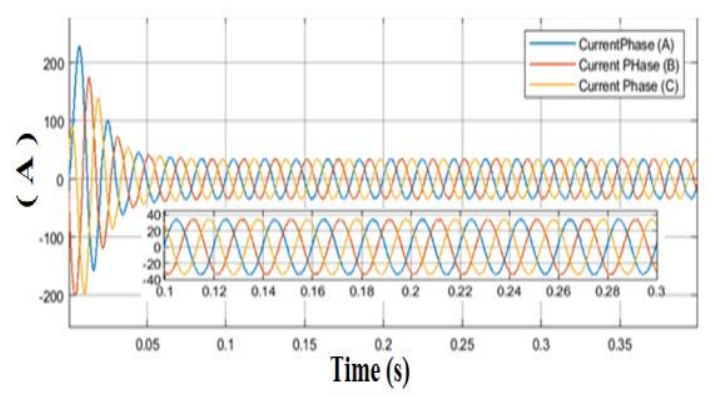

Figure 23. Three-phases current of source after compensation of DSTATCOM with hybrid system (battery and PV)

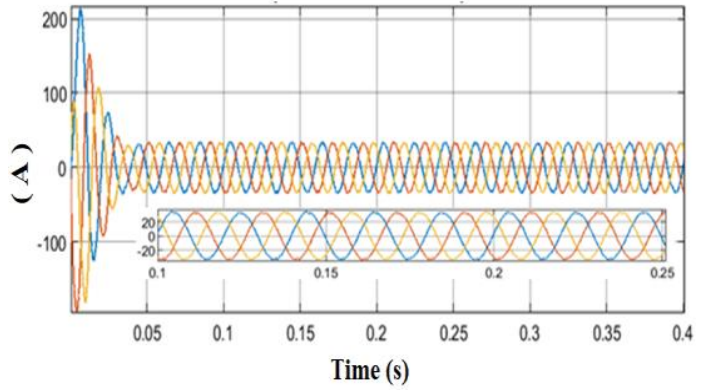

Figure 22. Three-phases current of source after compensation of DSTATCOM with PV

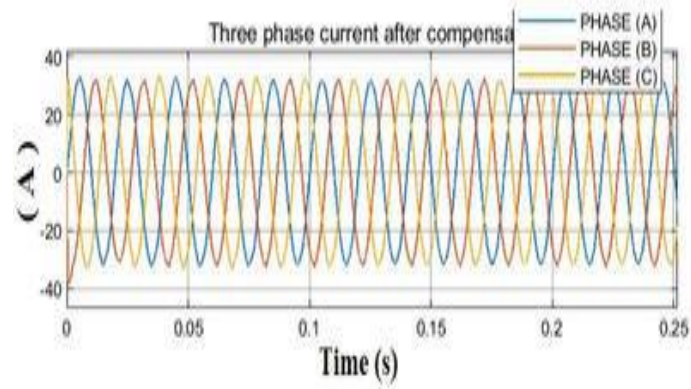

Figure 24. Three-phases current of source after compensation of DSTATCOM with hybrid system (battery and PV) in order to supply constant DC link voltage

Figure 25 shows, active power that has supplied from the generator, and equal $(43 \mathrm{~kW})$ when using DSTATCOM alone, it is noted, all active power of compensation takes from the source. And also shows the active power of DSTATCOM where equal zero because DSTATCOM is worked alone without (PV-Battery). Figure 26 shows the reactive power of the grid which equal $23.5 \mathrm{kvr}$ and reactive power of DSTATCOM equal $1.5 \mathrm{Kvar}$, it is affected by the current interruption in the interval of $0.3 \mathrm{~s}-0.7 \mathrm{~s}$ and reactive power of grid have a value $32 \mathrm{kvar}$ and reactive power of DSTATCOM equal 500var. Figure 27 explain active power of grid $(21 \mathrm{~kW})$ and active DSTATCOM power $(22 \mathrm{~kW})$ when DSTATCOM supply from a hybrid system. Figure 28 shows the reactive power of grid equal 700Var and reactive power of DSTATCOM and equal $24.5 \mathrm{kVar}$ and reactive power of grid equal 700var, it is affected by the current interruption in the interval of $0.3 \mathrm{~s}-0.7 \mathrm{~s}$ and reactive of DSTATCOM have a value $25.5 \mathrm{kvar}$ and reactive power of grid equal 100var, Active power of PV and active power of battery at radiation and constant temperature $500 \mathrm{~W} / \mathrm{m}^{2}, 25 \mathrm{C}^{\circ}$ shown in Figure 29.

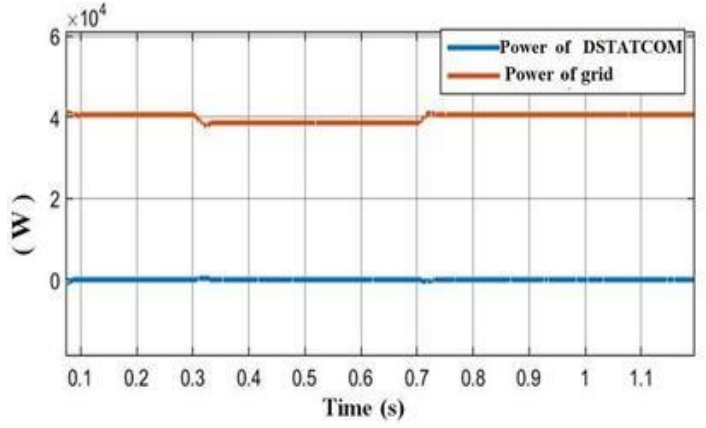

Figure 25. Active power of source and active power of DSTATCOM when DSTATCOM worked alone

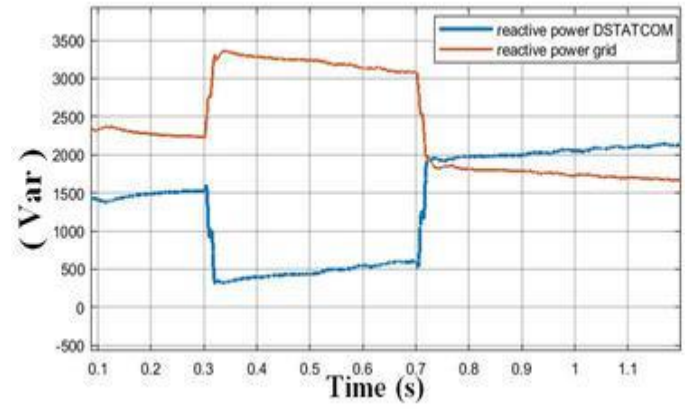

Figure 26. Reactive power of source and reactive power of DSTATCOM when DSTATCOM worked alone 


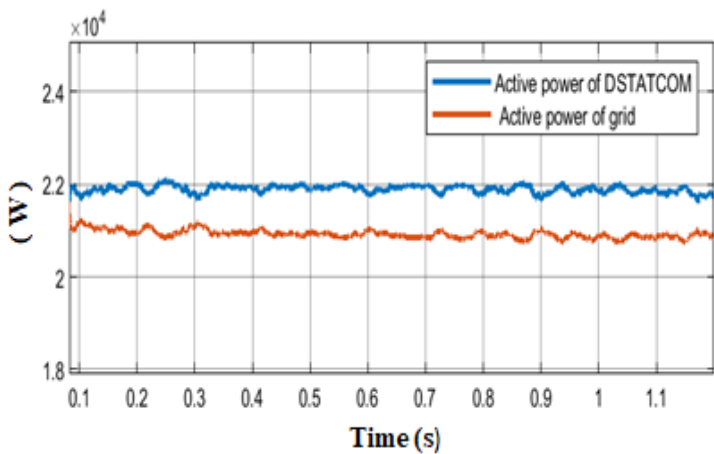

Figure 27. Active power of source and active power of DSTATCOM when DSTATCOM worked with hybrid system

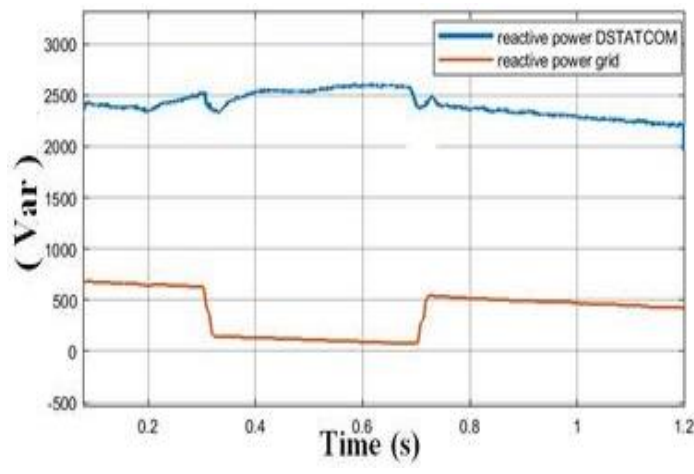

Figure 28. Rective power of source and reactive power of DSTATCOM when DSTATCOM worked with hybrid system

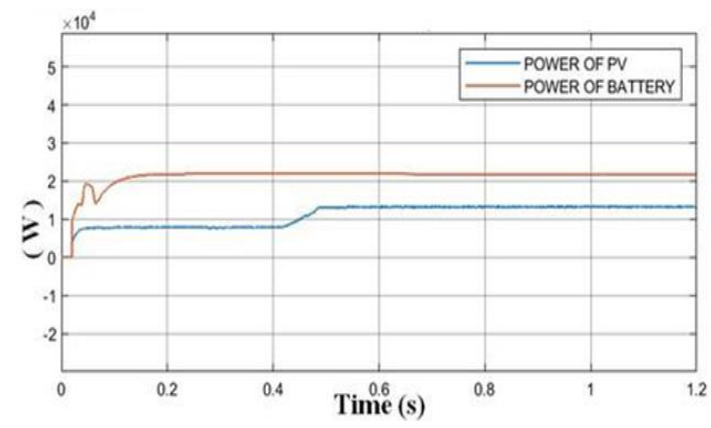

Figure 29. Active power of PV and active power of battery at the radiation and temperature are $500 \mathrm{~W} / \mathrm{m}^{2}, 25 \mathrm{C}^{\circ}$ respectively

\section{CONCLUSION}

Different types of DC power sources have been considered to evaluate the ability of compensation the shortage in active and reactive power to power quality improvement due to the disturbances the Nonlinearity of three-phase load or due to transient failure in such phases. A fast response system means a stable operation for the loads and generation unit. The time response and its effects on the active/reactive power with different types of external DC sources supply three-leg VSC for (DSTATCOM) have been compared. The hybrid system of PV-battery to supply the DC link voltage for STATCOM by using high coordination logical circuit has been applied for the first time. The hybrid performance has been compared with a constant DC-link voltage. The results illustrate that the hybrid DC system improved the compensation for source currents as well as THD for phase A concerning the performance of DSTATECOM supplied with constant DC voltage.

\section{REFERENCES}

[1] S. A. Khajehoddin, et al., "DC-Bus Design and Control for a Single-Phase Grid-Connected Renewable Converter with a Small Energy Storage Component," IEEE Transactions On Power Electronics, vol. 28, no. 7, pp. 3245-3254, Jul. 2013.

[2] S. Taghizadeh, et al., "A Fast and Robust DC-Bus Voltage Control Method for Single-Phase Voltage-Source DC/AC Converters," IEEE Transactions on Power Electronics, vol. 34, no. 9, pp. 9202-9212, Sep. 2019.

[3] F. Abed and Yarub Al-Douri, "Review on the energy and renewable energy status," Renewable and Sustainable Energy, vol. 39, pp. 816-827, Nov. 2014.

[4] P. Bhatnagar and R.K. Nema, "Maximum power point tracking control techniques: State-of-the-art in photovoltaic applications," Renewable and Sustainable Energy Reviews, vol. 23, pp. 224-241, Jul. 2013.

[5] I. M. Abdel-Qawee, et al, "Comparative study of the most efficient maximum power point tracking techniques for a photovoltaic system," International Journal of Advances in Applied Sciences (IJAAS), vol. 8, no. 1, pp. 73-82, Mar. 2019.

[6] D. F. Liu, et al., "AVariable Step Size INC MPPT Method for PV Systems," IEEE Transactions on Industrial Electronics, vol. 55, no. 7, pp. 2622-2627, Jul. 2008. 
[7] D. Verma, et al., "Maximum power point tracking (MPPT) techniques: Recapitulation in solar photovoltaic systems," Renewable and Sustainable Energy Reviews, vol. 54, pp. 1018-1034, Feb. 2016.

[8] S. D. Stallon et al., "High Efficient Module of Boost Converter in PV Module," International Journal of Electrical and Computer Engineering (IJECE), vol. 2, no. 6, pp. 758-781, Dec. 2012.

[9] O. P. Mahela, et al., "Power quality improvement in distribution network using DSTATCOM with battery energy storage system," Electrical Power and Energy Systems, vol. 83, pp. 229-240, Dec. 2016.

[10] I. Ranaweera, et al., "Residential photovoltaic and battery energy system with grid support functionalities," IEEE 6th International Symposium on Power Electronics for Distributed Generation Systems (PEDG), 2015.

[11] N. Prakash, et al., "Power quality improvement of grid inter connected hybrid system using STATCOM," International Journal of Advanced Engineering Technology, vol. 7, no. 2, pp. 1225-1233, 2016.

[12] Sarina A. and Fangxing Li, "Coordinated V-f and P-Q Control of Solar Photovoltaic Generators with MPPT and Battery Storage in Microgrids," IEEE Transactions On Smart Grid, vol. 5, no. 3, pp. 1270-1281, May 2014

[13] E. Dursun and O. Kilic, "Comparative evaluation of different power management strategies of a stand-alone PV/Wind/PEMFC hybrid power system," International Journal of Electrical Power \& Energy Systems, vol. 34, no. 1, pp. 81-89, Jan. 2012.

[14] Ajeeth Kumar S, Shabarish G and Kishore Kannan A, "IoT Based Wind/Solar Hybird Inverter," International Journal of Advances in Applied Sciences (IJAAS), vol. 5, no. 3, pp. 137-140, Sep. 2016.

[15] F. S. Ahmed, et al., "Power quality improvement by using multiple sources of PV and battery for DSTATCOM based on coordinated design," Iop Conference Series Materials Science and Engineering, vol. 745, pp. $1-18,2020$.

[16] M. A. Kamarposht, et al., "Performance Comparison of STATCOM \& SVC in Reactive Power Control Strategy for Wind Farm," Journal of World's Electrical Engineering and Technology, vol. 3, no. 1, pp. 6-17, 2014.

[17] M. S. El-Moursi, et al., "Novel Controllers for the 48-Pulse VSC STATCOM and SSSC for Voltage Regulation and Reactive Power Compensation," IEEE Transactions on Power Systems, vol. 20, no. 4, pp. 1985-1997, Nov. 2005

[18] A. G. Shaik, "Power quality assessment and event detection in hybrid power system," Electric Power Systems Research, vol. 161, pp. 26-44, 2018.

[19] O. P. Mahela and A. G. Shaik, "Power Quality Recognition in Distribution System with Solar Energy Penetration Using S-Transform and Fuzzy C-Means Clustering," Renewable Energy (Elsevier), vol. 106, pp. 37-51, Jun. 2017.

[20] N. Geddada, et al., "Synchronous reference frame based current controller with SPWM switching strategy for DSTATCOM applications," IEEE International Conference on Power Electronics, Drives and Energy Systems, pp. 16-19, Dec. 2012.

[21] A. K Pandey, et al., "Compensation of neutral current using unit vector template method-based control algorithm for DSTATCOM to power quality improvement," International Journal of ScienceEngineering and Technolog, vol. 6, no. 2, pp. 154-159, 2018.

[22] J.M. Maza-Ortega, et al., "Overview of power electronics technology and applications in power generation transmission and distribution," Journal of Modern Power System and Clean Energy, vol. 5, no. 4, pp. 499-514, Jul. 2017.

[23] H.L. Jou, et al., "Novel power converter topology for three phase four wire hybrid power filter," IET Power Electronic, vol. 1, no. 1, pp. 164-173, Mar. 2008.

[24] A. N. Hussain, et al., "Power System Oscillations Damping by Optimal Coordinated Design between Multiple Damping Stabilizers Based on STATCOM Device," IEEE Conference on Sustainable Utilization and Development in Engineering and Technology, pp. 18-23, 2012.

[25] Aman Sofiya, et al, "A Wide Compensation Ranged Hybrid Statcom with Low DC-Link Voltage," International Journal of Innovative Science and Research Technology, vol. 3, no. 5, pp. 838-841, May 2018.

[26] M. N. Kabi, et al., "Coordinated control of grid connected photovoltaic reactive power and battery energy storage systems to improve the voltage profile of a residential distribution feeder," IEEE Transactions on Industrial Informatics, vol. 10, no. 2, pp. 967-977, Jul. 2014.

[27] B.N. Singh, et al., "Design, simulation and implementation of three-poleffour-pole topologies for active filters," IEE Proceedings - Electric Power Applications, vol. 151, no. 4, pp. 467-476, Jul. 2004.

[28] B. Singh and S. R. Arya, "Design and control of a DSTATCOM for power quality improvement using cross correlation function approach," International Journal of Engineering, Science and Technology, vol. 4, no. 1, pp. 74-86, 2012.

[29] V. K. Kannan and N. Rengarajan, "Photovoltaic based distribution static compensator for power quality improvement", Electrical Power and Energy Systems, vol. 42, no. 1, pp. 685-692, 16 June 2012.

[30] S. Gomathy, et al., "Design and implementation of Maximum Power Point Tracking (MPPT) algorithm for a standalone PV system," International Journal of Scientific \& Engineering Research, vol. 3, no. 3, pp. 1-7, 2012.

[31] S. Y. Prasad, et al., "Microcontroller based intelligent DC/DC converter to track Maximum Power Point for solar photovoltaic module," IEEE Conference on Innovative Technologies for an Efficient and Reliable Electricity Supply, pp. 94-101, Nov. 2010.

[32] N. Omar, et al., "Lithium iron phosphate based battery Assessment of the aging parameters and development of cycle life model," Applied Energy, pp. 1575-1585, Jan. 2014.

[33] P. Horkos, et al., "Review on Different Charging Techniques of Lead- Acid Batteries," Third International Conference on Technological Advances in Electrical, Electronics and Computer Engineering (TAEECE), pp. 27-32, Apr. 2015. 
[34] T. sukanth, et al., "Comparative Study Of Different Control Strategies For Dstatcom," International Journal of Advanced Research in Electrical, Electronics and Instrumentation Engineering, vol. 1, no. 5, pp. 362-368, 2012

[35] R. S. Herrera and P. Salmerón, "Instantaneous Reactive Power Theory: A Reference in the Nonlinear Loads Compensation," IEEE Transactions on Industrial Electronics, vol. 56, no. 6, pp. 2015-2022, Jun. 2009.

[36] M. K. Ghartemani, et al., "Problems of Startup and Phase Jumps in PLL Systems," IEEE Transactions on Power Electronics, vol. 27, no. 4, pp. 1830-183, Apr. 2012.

\section{BIOGRAPHIES OF AUTHORS}

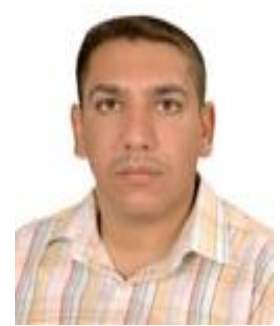

Ali Nasser Hussain was born in Iraq on April 30, 1974. He received his B.Sc. and M.Sc. in Electrical \& Electronics Engineering, University of Technology, Baghdad, Iraq, in 1998 and in 2005 respectively and his $\mathrm{PhD}$ degrees in Electrical Engineering from University Malaysia Perlis (UniMAP), Perlis, Malaysia in 2014. Since 2004 he is a senior lecturer in the Electrical Engineering Technical College at Middle Technical University. His current research interests include power system operation and control, electrical power system stability and intelligent optimization, renewable energy, robust control.

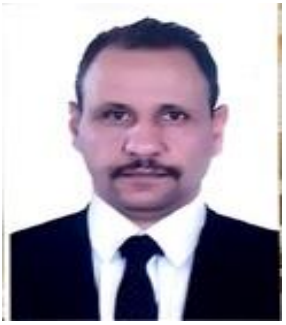

Dr. Ahmed J. is a lecturer at Dep. of power engineering technology/ Engineering Technical College/Mosul. He has get BSc.and Msc. From Al-Thechnologia Unversity/ Baghdad In 1995 and 2004 respectively in Electrical Engineering. He has finish his Ph.D. in Electrical Machines from university of Mosul in 2012. He has been Bunsvuer Univesity /Germany in Research Scholarship for 6 months during his Ph.D. studying period.His filed of work concentrate on Adaptive and Intelgent control Systems, Electric machines Designe and Drives. Now he is Head Dep. of Power Engineering Technology at Engineering Technical College/Mosul.

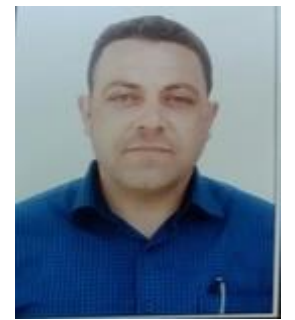

Firas Saaduldeen Ahmed was born in Iraq on april 16, 1984. He received his B.Sc. in Electrical Power Engineering Techniques,Technical Engineering College/Mosul, Northen Technical University, Mosel Iraq, in 2007. He is currently pursuing his MSc program in Electrical Technical Engineering with emphasis in power quality improvement using STATCOM equipped with hybrid of a solar cells and battery energy storge. 